\title{
Pharmaceutical Personal Selling: Problems Prospects And Importance Of Strategic Relationship Marketing
}

\author{
Mohammad Ovais ${ }^{1}$, Mohammad Imran Wazir ${ }^{2}$, Owais Mufti ${ }^{3}$
}

\begin{abstract}
In Pakistan the Pharmaceutical industry is important as it essentially and strategically operates for population well being by providing good life saving yet cost efficient healthcare products. Marketing in this sector is often done through the trained sales personnel called as Medical Representatives (Medical Reps). However the affectivity of the medical sales calls done by these sales persons in the physician's chamber is almost negligible. This research has presented a relationship model that not only can increase sales call effectiveness but also provide important managerial implications. Data was collected from medical sales persons and physicians regarding the three key dimensions of relationship marketing; the customers, the sales persons and the suppliers. The study focused to develop an optimal model for personal selling practices to develop a long term mutually beneficial relationship between sales people and physicians. A theoretical model is developed in view of the Pakistan's specific context, current environmental factors and digital and social media like community websites, face book and other corporate blogs and Medical Communities and their websites etc.
\end{abstract}

Key Words: Personal Selling, Pharmaceutical, Relationship Manager, Sales Call Effectiveness.

\section{Introduction}

\section{Relationship Marketing:}

The concept of Relationship Marketing (RM) originated in start of 1980, with a primary focus on developing long term mutually profitable relationship between the company and its target customer group mainly derived from the industrial marketing literature (Jackson, 1985 and Gronroos, 1990). Many marketing professionals now agree that marketing must be no more considered as a series of continuous and independent transactions but a dynamic process of developing, retaining and expanding long term relationships with the cus-

1 MS (Marketing) Lecturer in Marketing Cecos University Peshawar, umerkhelovais@gmail.com

2 Lecture in Marketing IMSciences Peshawar, wazir.imran@gmail.com

3 Lecture in Marketing IMSciences Peshawar, owaismufti@hotmail.com 
tomers. According to Kotler relationship marketing can be applied when the products are competitive and there is a periodic need for the product. Authors like Fornell and Wernerfelt (1995) describe relationship marketing as the defensive marketing comprising of two main components; getting new customers and retaining current ones. Retention of the current customers is one of the basic components of the relationship marketing. Using different tools to prevent and reduce preexisting customers' defection and getting and growing new customers by establishing long term mutually rewarding relationships.

\section{The Six-Market Model:}

However, the concept evolved with the passage of time and finally got a holistic shape when Christopher M. \& Payne A. (1991) presented the Comprehensive model of incorporating and integrating marketing function inside an organization (creating superior customer value) and beyond i.e. managing relationship with distributors, suppliers and public institutions. The authors presented a comprehensive model of RM based on following six key dimensions: Customer market, internal market, supplier market, referral market, influence markets \& employee markets.

Termed as the six-market model, this model presents RM as the comprehensive and integrated marketing function to develop long term relationship between the company and all the six market domains, in order to ensure long term mutually beneficent business relationship. The model initially presented internal markets as the key drive for building long term relationship with the customers. However, it was continuously modified and revised based on the context \& understanding of the relationship and the contribution of the different domains/dimensions of the model. Finally the model was presented in its most effective form by taking the customers markets as the facilitator and integrator for the other five dimensions of the model, as shown in figure-1 (Craven, 1994).

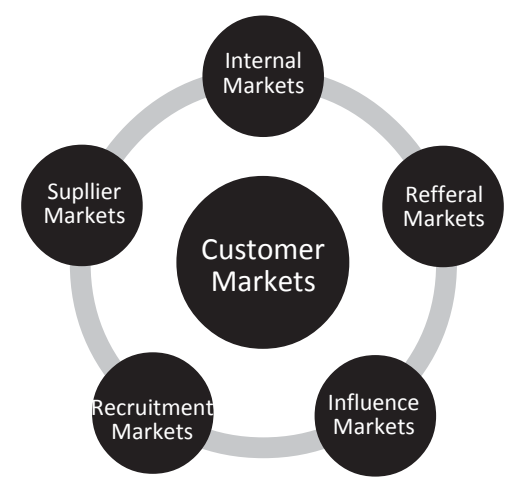

Figure $1^{(5)}$ Source: Craven (1994) Journal of Marketing, Vol. 70(3). 8. 
The benefits of customer retention have been proven to the business community by many researchers (Riechheld, 1990 Reichheld, 1993). Another study also confirms that in the view of experienced marketing executives and professionals, relationship building is becoming the most important and vital tool for the marketers and that this is equally important at all level of organization (Chartered Institute of Marketing, 1994).

Abundant literature has proven the crucial contribution of employees at all the level of organization and their vital role in marketing effectiveness (Gronroos, 1990). Other studies on organizational behavior establish the critical role of employee's satisfaction to customer retention (Schlesinger, 1991 and Bradford, 2008). Salespeople that have a relationship orientation have proven to be more effective in marketing communication. The relationship orientation is defined as, "a relatively stable, focus to develop long term relationship with the customers with a major predisposition to value". Research shows that, salespeople with relationship orientation and developed skills to manage relationships, for example emotional intelligence, are more successful in building relationships with the key customers (Bradford, 2008).

The role of supplier is critical especially in the pharmaceutical industry, not only for the availability of products but also to measure responses, get feedbacks and forecast future sales etc. From relationship marketing point of view the supplier's relationship is crucial as it provides the merger point for network literature and marketing (Hunt, 1994 and Christopher, 1995). Supplier's database can enable marketers in the pharmaceutical industry to effectively implement marketing activities, explore and target potential customers and areas and manage performances.

Referrals have a massive role in developing relationship between an organization and its customers. This is also important to some extent in pharmaceutical marketing and sales management. The roles of Recruitment Markets and Influence Markets are also important, but keeping in view the complex and detail extensive nature of the products and the context of this study they won't be considered that much.

Overall the key dimensions of six market model call for three main aspects as vital for effective RM (Payne, 1995).

$>\quad$ The long term relationship focus

$>$ The flexible organizational structure \&

> The new role of Marketing Manager 
According to researchers the model by Payne not only enforces superior value creation for customer's satisfaction but also the superior efficiency in responding to customers to increase customer's loyalty, which ultimately calls for the modification of organizational structure and culture into a network form that is more responsive and flatter. This broadened view defines a new role of the marketing manager in this turbulent and dynamic world (The Economist, 1994, David, 2010). A lot of research has been proven and reinforced this broadened approach of RM and many scholars have accepted and endorsed the concept (Kotler, 1992 and Morgan, 1994).

\section{Marketing practices in Pakistan Pharmaceutical Industry:}

Pharmaceutical industry of Pakistan is the important for the economy because of its essential and strategic role for population well being and efficient but economic health care provision. The industry is well developed and has skilled personnel at various functional areas, i.e. production, quality control, management and marketing etc. The market comprises of larger multinational organizations also called as multinational companies (MNCs) and relatively smaller national organizations also called as national companies (NCs). Majority of the companies are licensed for good manufacturing practices. Pakistan is a potential market for Pharmaceutical Industry (PI) because of its growing population, growing economy and increasing awareness of the people, with an annual expected growth rate of $11 \%$ (Doyle, 1995).

Marketing in pharmaceutical sector is highly controlled and regulated, (IMS Health, 2010) it involves;

\section{Directed to Prescribers Advertisement:}

Pharmaceutical companies spend millions on direct to prescriber advertisement, through advertisement in professional publications, books, journals, conferences electronic media and cyber space (Mishra, 2004).

\section{Sponsorships:}

Involves study tours, attending conferences, event arrangement, national and multinational studies conductance, entertainment tours.

\section{Pharmaceutical Personal Selling:}

Personal selling is vital among these three. Because of the business to business (B2B) nature of marketing, pharmaceutical companies have to 
primarily depend on personal selling to promote their products in the market as the target audience and customers are different, who are not the end users but merely influencers (Masood, 2009). These influencers are medical practitioners referred to as doctors or physicians by general public. Companies' major objective is to convince this distinct class of customers to prescribe companies' products to their ultimate customers i.e. patients. They train their field force or sales force extensively to promote their products to this distinct, knowledgeable, skilled and highly rational customers' class (OSEC, 2008).

\section{The Pharmaceutical Sales Cycle:}

The pharmaceutical sales process involves a number of key role players like; the companies with their products, the sales peoples, the Customers (Physicians), the end user (patients), the retail pharmacies \& the distributors. The sales process starts with an effective detailing of the sales person also called as the medical representatives (short form, med reps) to the doctors, who if convinced, prescribes the medicine to their patients and patients then purchases the medicine from the nearby retail chemists/pharmacies. The medicines are supplied to the retail pharmacies by a licensed distributor of that particular company upon their subsequent order (IMP, 2004). (Figure: 2). As evident from figure 1 the role of supplier or distributor is critical in pharmaceutical industry to ensure better availability of the products and measure customer's responses in the form of sales generated in the respective area.

\section{Sales Cycle and the Role of Supplier/Distributor:}

The role of supplier or distributor is crucial and critical at this stage, as he is the company's only credible source to ensure, end user's access to their products. There is an active \& huge whole sale market but it is also dependent upon the supplies and discounts of the pre-assigned distributors. If there is a leniency from the distributor side i.e. unavailability of the products at retail pharmacy, the effects are drastic from perspectives like; loss of sale, negative impact on the sales person and customer's relationship and customer may switch to other product, as availability a lot of options for the same indication or product parity makes the customer/physician highly vulnerable for switch.

That is why the supplier's management is also a critical factor for the sales of pharmaceutical products (IMP, 2004). 


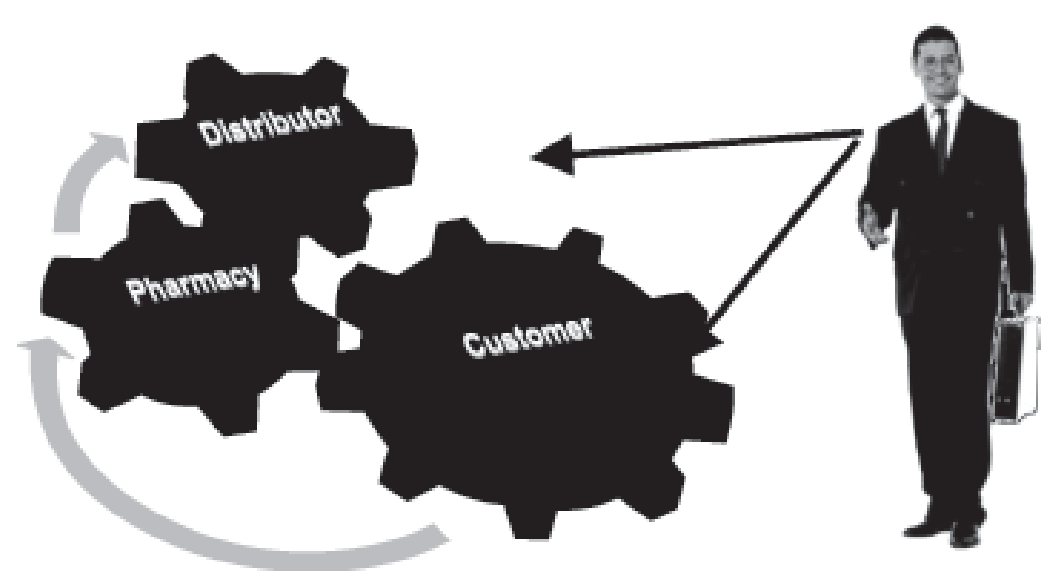

Figure 2

\section{The Role of Relationship Marketing in Pharmaceutical Industry:}

Many marketing professional agree that retaining a current customer is 20 times less costly than developing a new one (Keller, 2008). That's why increased emphasis must also be placed on retaining the potential physicians (Reichheld, 1994). A lot of research has proven the impact of both customer and sales person relationship (Boles, 1997), and the company's overall relationship with the customers for long term mutually beneficent business to business relationship (Helen, 2003) However, little emphasis is put on the role of RM in the pharmaceutical industry to develop long term mutually beneficent sales generating relationships. The subject also needs deliberate and cautious adjustment to the cultural context in Pakistan's market especially in Peshawar where relationship is much based on core cultural values than on the rational parameters (Palmer, 1995).

\section{Need for the Study:}

The discussion above clearly establishes the fact that relationship marketing or personal selling with customer orientation is critical in pharmaceutical industry. However, following factors have made personal selling almost ineffective;

a) Complex and detailed intensive nature of products

b) Too many Medical representatives

c) Lack of long term focus \&

d) Time constrained very rigid and knowledgeable customer (Masood, 2009). 
In addition, lack of focus on long term relationship building \& customer orientation and heavy dependence on short term transactional marketing have further aggravated the situation. This situation clearly calls for an optimal personal selling model or mix to ensure long term mutually beneficent relationship with the customers and get maximum return on investment.

\section{Research Objective:}

The objective of this research was to develop an optimal framework/model of the relationship marketing for the current personal selling practices in pharmaceutical industry by collecting and analyzing empirical data collected from med reps and physicians.

\section{Methodology:}

Although the effectiveness of the sales call is much dependent upon the medical representative's developed skills knowledge and competencies in interpersonal communication. The study however, took all these as constant because the data was collected from a diverse sample of both national and multinational companies. To further minimize the doubt a standard value of $50 \%$ was taken as standard for the effectiveness of personal selling in both the medical representative and physicians cases. i.e if $50 \%$ of the respondents graded current personal selling as effective, they were confirmed as effective and vice versa. Later the study findings were used to develop a theoretical model for generating long term mutually beneficent relationship between pharmaceutical sales people customers and suppliers to ensure maximum return on investment.

Using 2 types of comprehensive questionnaire data was collected about the above mentioned three key dimensions of RM from a sample of 100 responders including, 25 customers, (Physicians), and 75 pharmaceutical sales representatives. Respondents were selected from diverse companies. 40 medical representatives were selected from multinational pharmaceutical companies and 35 from national companies across two big cities of Pakistan that is, Peshawar and Islamabad, so as to get a diverse response to be generalized to overall market. The primary focus of the questions was to explore the responses in terms of behavior, attitude and overall concept and evaluation of the pharmaceutical personal selling practices by both the sales people and physicians in order to determine the focus on relationship building or transactions. The behavioral aspects were chosen to get response regarding the role of Relationship Marketing towards call effectiveness. Questions were asked about following areas; 
A. The medical representative's perception about his job description

B. The effectiveness of the current personal selling practices

C. The type of promotional tool, most effective

D. The availability of sufficient time at physician's chamber

E. The role of supplier in facilitating long term relationship

F. The type of problems frequently solved in physicians' chambers

G. The physicians' perception about the role of medical representatives, their contribution to clinical practice, their recommendations and role of suppliers to the physicians' clinical practice.

The outcomes were analyzed through regression and correlation analysis using SPSS. Later, the study findings were used to develop a theoretical model for generating long term mutually beneficent relationship between pharmaceutical sales people customers and suppliers to ensure maximum return on investment.

This research explored the customers' perception through a separate questionnaire in the following four areas;

1. Perceptions of the overall industry

2. Perceptions of the value provided by the sales people

3. Perceptions about orientation of the sales people, transactional versus long term problem solving and relationship building by contribution to clinical practices

4. Physician's perception about the availability of medicine.

The study primarily focused on getting insights into the sales person's overall view of the job, view of the customers, view of the supplier, customer orientation, the hurdles in the routine sales process and their recommendations on a comprehensive questionnaire. Data was collected from the respondents regarding, suppliers' area/customer coverage, optimal accessibility options, the sales people-supplier-company coordination and integration and possibilities of any support in the marketing and sales process. The external environmental factors like wheather and other conditions also interfere in the 
supply process that is why a mean of 30 would be taken as feasible for both the medical representatives and physicians' negative responses.

\section{Research Hypotheses:}

The data collected was analyzed using SPSS for the relative effect of the each of the dimension of RM and their mutual interdependencies upon effectiveness of the personal selling practices, based on the following hypotheses;

A. Current pharmaceutical personal selling practices are ineffective.

B. Long term customer relationship and medical representatives orientation of it has a significant impact on medical call effectiveness.

C. Customer/Physician's perception of the medical representative's contribution to his clinical practices also significantly impact call effectiveness.

D. Supplier has a significant role in long term relationship between medical representative and physician.

E. The relationship between medical representative/physician and supplier significantly impact long term relationship and thus call effectiveness.

The theoretical frame work developed is diagrammatically represented in the figure below;

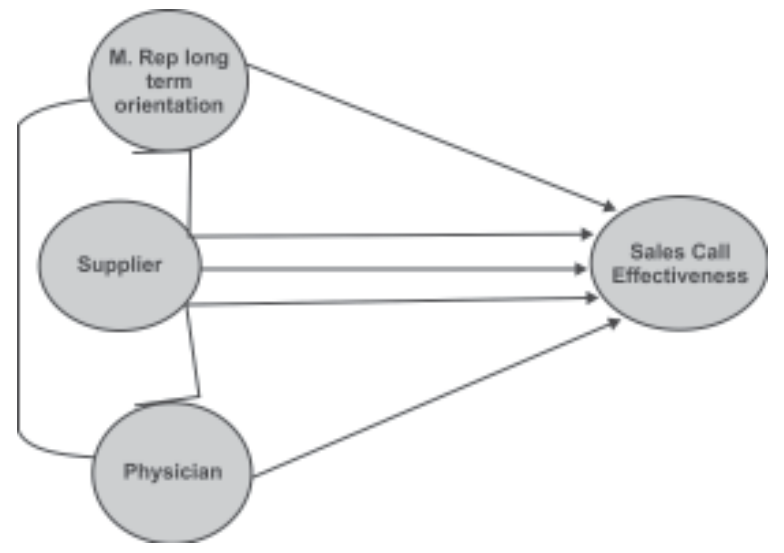

(Thoretical Frame Work) 


\section{DISCUSSION OF RESULTS:}

\section{Study Outcomes:}

The study outcomes were collected based on the responses from both type of respondents i.e the medical representatives and customers regarding different behavioral aspects that explained the effectiveness of current personal selling practices and medical representatives orientation and customers' perception about the marketing approaches and role of relationship marketing. The responses to different questions are summarized as follows;

\section{Effectiveness of Personal Selling:}

Two hypotheses were developed to judge the outcomes of the study regarding the effectiveness of the personal selling in pharmaceutical industry;

Null hypothesis $=\mathrm{H}_{\mathrm{o}}=$ the pharmaceutical personal selling practices are effective.

Alternate hypothesis $=\mathrm{H}_{1}=$ the pharmaceutical personal selling practices are in-effective.

Responses about the first research questions were collected by asking whether the current personal selling practices were effective or not? A highly significant negative response was shown by the respondents of both the categories as shown in the tables. As evident from table-1, a cumulative $65 \%$ of the medical representative either disagreed or strongly disagreed regarding the effectiveness of the current personal selling practices.

Table 1: The current personal selling is effective

\begin{tabular}{|l|c|c|c|c|}
\hline & Frequency & Percent & $\begin{array}{c}\text { Valid } \\
\text { percent }\end{array}$ & $\begin{array}{c}\text { Cumulative } \\
\text { percent }\end{array}$ \\
\hline Valid Strongly disagree & 17 & 22.7 & 22.7 & 22.7 \\
\hline Disagree & 32 & 42.7 & 42.7 & 65.3 \\
\hline Neutral & 6 & 8.0 & 8.0 & 73.3 \\
\hline Agree & 12 & 16.0 & 16.0 & 89.3 \\
\hline Strongly agree & 8 & 10.7 & 10.7 & 100.0 \\
\hline Total & 75 & 100.0 & 100.0 & \\
\hline
\end{tabular}


These findings are also significant ( $\mathrm{p}$-value 0.000 ) as for our predefined criteria, that at least $50 \%$ of the medical representative must grade current practices as effective. (Table 2) Based on these findings we accept our alternate hypothesis that the current pharmaceutical personal selling practices are in-effective.

Table 2: One-Sample Test ( Sales call effectiveness)

\begin{tabular}{|l|l|l|l|l|l|l|}
\hline & \multicolumn{3}{|l|}{ Test Value $=50$} \\
\cline { 2 - 6 } & $\mathrm{t}$ & $\mathrm{df}$ & $\begin{array}{l}\text { Sig. (2- } \\
\text { tailed) }\end{array}$ & $\begin{array}{l}\text { Mean dif- } \\
\text { ference }\end{array}$ & \multicolumn{2}{|l|}{$\begin{array}{l}\text { 95\% confidence inter- } \\
\text { val of the difference }\end{array}$} \\
\cline { 3 - 7 } & & 74 & .000 & -47.507 & -47.81 & -47.21 \\
\hline $\begin{array}{l}\text { the current } \\
\text { personal sell- } \\
\text { ing is effective. }\end{array}$ & -316.874 & & & & & \\
\hline
\end{tabular}

These findings clearly establish an immediate need for a modification of the current approaches of personal selling in the pharmaceutical industry. Research has proven that sales people role perception and job definition have strong impact on the performances of sales people (Brown, 2005). Bryan Tracy (1999) in his book personal selling and sales management quotes that, "personal selling is contagious, the more embedded the features of the products are in the sales representative's behaviors and emotions the higher the impact on the customer and vice versa'. The perception of the sales representatives about ineffectiveness of their effort is typically because of the negative or negligible customers/physicians' response and clearly call for a strategic focus.

The physicians' response was also consistent with the medical representatives as given in the table 3 .

Table 3: Medical representatives contribute towards clinical practice

\begin{tabular}{|c|c|c|c|c|}
\hline & Frequency & Percent & $\begin{array}{c}\text { Valid } \\
\text { percent }\end{array}$ & $\begin{array}{c}\text { Cumulative } \\
\text { percent }\end{array}$ \\
\hline Valid Strongly disagree & 14 & 56.0 & 56.0 & 56.0 \\
\hline Disagree & 6 & 24.0 & 24.0 & 80.0 \\
\hline Neutral & 3 & 12.0 & 12.0 & 92.0 \\
\hline Agree & 2 & 8.0 & 8.0 & 100.00 \\
\hline Total & 25 & 100.0 & 100.0 & \\
\hline
\end{tabular}


The response was very curios as shown by table 3, 56\% of customers strongly disagreed that current personal selling practices are effective, while cumulative $80 \%$ confirmed the ineffectiveness of the current practices. In addition when compared with the standard value of $50 \%$ these findings were also highly significant at a p-value of 0.000 proving current pharmaceutical personal selling practices as ineffective as given in table 4 .

Table 4: One-Sample Test (Personal Selling is ineffective)

\begin{tabular}{|l|l|l|l|l|l|l|}
\hline \multirow{2}{*}{} & \multicolumn{2}{|l|}{ Test Value $=50$} \\
\cline { 2 - 7 } & $\mathrm{t}$ & $\mathrm{df}$ & $\begin{array}{l}\text { Sig. (2- } \\
\text { tailed) }\end{array}$ & $\begin{array}{l}\text { Mean dif- } \\
\text { ference }\end{array}$ & \multicolumn{2}{|l|}{$\begin{array}{l}\text { 95\% confidence inter- } \\
\text { val of the difference }\end{array}$} \\
\cline { 3 - 7 } & & & & & Lower & Upper \\
\hline $\begin{array}{l}\text { Med reps con- } \\
\text { tribute towards } \\
\text { clinical practice }\end{array}$ & -246.378 & 24 & .000 & -48.280 & -48.68 & -47.88 \\
\hline
\end{tabular}

The findings in table 3 and 4 also reinforce our alternate hypothesis and prove the ineffectiveness of personal selling in pharmaceutical industry.

\section{Benefits of Relationship Marketing:}

\section{Medical Representative -Physician relationship:}

Various behavioral aspects were analyzed and evaluated to determine the nature of the relationship between medical representatives based on the customer's perceptions and medical representatives' orientation and focus. While defining their job only $11 \%$ of the respondents in medical representatives called themselves as problem solvers for their customers while a massive $67 \%$ cumulative either described themselves as sample providers? (31\%) or drug sellers $(36 \%)$, less than $11 \%$ described themselves as problem solvers for their customers (table 5) clearly showing their short term transactional approach.

Table 5: How do you define your job?

\begin{tabular}{|l|c|c|c|c|}
\hline & Frequency & Percent & $\begin{array}{c}\text { Valid } \\
\text { percent }\end{array}$ & $\begin{array}{c}\text { Cumulative } \\
\text { percent }\end{array}$ \\
\hline Valid problem solver & 8 & 10.7 & 10.7 & 10.7 \\
\hline sample providers & 23 & 30.7 & 30.7 & 41.3 \\
\hline personal services & 17 & 22.7 & 22.7 & 64.0 \\
\hline drug sellers & 27 & 36.0 & 36.0 & 100.0 \\
\hline Total & 75 & 100.0 & 100.0 & \\
\hline
\end{tabular}


Very consistent with these findings were the response of the physicians, $68 \%$ of the physicians cumulative either graded medical representatives as sample providers (24\%) or drug sellers (44\%), (table 6) reaffirming the short term transactional approach of the medical representatives. Only $8 \%$ of the physicians regarded them as problem solvers.

Table 6: How do you grade med. reps?

\begin{tabular}{|l|c|c|c|c|}
\hline & Frequency & Percent & $\begin{array}{c}\text { Valid } \\
\text { percent }\end{array}$ & $\begin{array}{c}\text { Cumulative } \\
\text { percent }\end{array}$ \\
\hline Valid problem solver & 2 & 8.0 & 8.0 & 8.0 \\
\hline sample provider & 6 & 24.0 & 24.0 & 32.0 \\
\hline $\begin{array}{l}\text { personal services } \\
\text { provider }\end{array}$ & 6 & 24.0 & 24.0 & 56.0 \\
\hline drug sellers & 11 & 44.0 & 44.0 & 100.0 \\
\hline Total & 25 & 100.0 & 100.0 & \\
\hline
\end{tabular}

The outcomes were also consistent with these findings when regressed for any relationship between dependent (call effectiveness) and independent variables. (Table 7,8 )

Table 7: ANOVA ${ }^{\mathrm{b}}$ (Effectiveness of personal selling)

\begin{tabular}{|c|c|c|c|c|c|c|}
\hline \multicolumn{2}{|c|}{ Model } & Sum of Squares & df & Mean Square & $\mathrm{F}$ & Sig. \\
\hline 1 & Regression & 32.490 & 4 & 8.122 & 6.163 & $.000^{\mathrm{a}}$ \\
\hline & Residual & 92.257 & 70 & 1.318 & & \\
\hline & Total & 124.747 & 74 & & & \\
\hline
\end{tabular}

a. Predictors: (Constant), Type of customers' problems oftenly solved., Do you get sufficient time in physician's chamber?, What is the most effective tool?, How do you define your job?

b. Dependent Variable: the current personal selling is effective.

The model proved to be a good fit with an $\mathrm{F}$ value $=0.000$. (Table 7)

Two of the variables time availability in the physician's chamber and the medical representative perception about the relative effectiveness of the different promotional tools had a significant impact upon the call effectiveness. $\mathrm{P}$ values 0.001 and 0.014 respectively (Table 8 ). The other variable the medical representative description of the job and type of customer problem often solved had not a significant impact on call effectiveness. 
Table 8: Coefficients ${ }^{\mathrm{a}}$

\begin{tabular}{|c|c|c|c|c|c|}
\hline \multirow{2}{*}{ Model } & \multicolumn{2}{|c|}{$\begin{array}{c}\text { Unstandardized Co- } \\
\text { efficient }\end{array}$} & $\begin{array}{c}\text { Standardized } \\
\text { Coefficients }\end{array}$ & & Sig. \\
\cline { 2 - 6 } & B & Std. Error & Beta & $\mathbf{t}$ & .005 \\
\hline $1 \quad$ (Constant) & 2.288 & .788 & .904 & .017 & .987 \\
\hline $\begin{array}{c}\text { How do you define } \\
\text { your job? }\end{array}$ & .002 & .137 & .002 & 3.477 & .001 \\
\hline $\begin{array}{c}\text { Do you get suffi- } \\
\text { cient time in phy- } \\
\text { sician's chamber? }\end{array}$ & .526 & .151 & .386 & -2.534 & .014 \\
\hline $\begin{array}{c}\text { What is the most } \\
\text { effective tool? }\end{array}$ & -.307 & .121 & -.269 & -.099 & .921 \\
\hline $\begin{array}{c}\text { Type of customer's } \\
\text { problems oftenly } \\
\text { solved. }\end{array}$ & -.014 & .142 & -.010 & & \\
\hline
\end{tabular}

a. Dependent Variable: the current personal selling is effective.

As discussed earlier that because of the complex nature and high risk of side effects and drug interactions pharmaceutical products are considered as detail intensive and require time in the physician chamber to present and emphasize the product's benefits and convince physician (Masood, 2009). This means call effectiveness plays the vital role. Medical representatives who had a long term orientation by considering them as problem solver were able to get significantly greater time than those with short term transactional focus. Ultimately those who get higher proportion of time in the physician's chamber also had very significant call efficiency (Table 9). Therefore indirectly those who had a long term focus and orientation can secure better call efficiency.

The findings in table 9 prove the alternate hypothesis to be true, that there is a significant relationship between the call effectiveness and variable that in turn represent the efforts to establish long term relation with the customer, the Relationship Marketing. The outcomes also suggest that type of customer problem solved was often short term and without the focus of problem solving and relationship building, which did not lead to any effectiveness in the impact of call.

These findings are also consistent with the responses of physicians who also graded the problem solving role of medical representative and their relationship with them as significant contributors towards their clinical practice and thus call effectiveness. (Table 10,11) 
Table 9: Correlations (Call Effectiveness)

\begin{tabular}{|c|c|c|c|}
\hline & $\begin{array}{c}\text { How do } \\
\text { you de- } \\
\text { fine you } \\
\text { job }\end{array}$ & $\begin{array}{c}\text { The current } \\
\text { personal } \\
\text { selling is } \\
\text { effective }\end{array}$ & $\begin{array}{c}\text { Do you get } \\
\text { sufficient time } \\
\text { in physician's } \\
\text { chamber? }\end{array}$ \\
\hline $\begin{array}{c}\text { How do you define Pearson } \\
\text { Correlation job? } \\
\text { Sig. (2-tailed) }\end{array}$ & 1 & -.151 & $-.344^{* *}$ \\
$\mathrm{~N}$ & 75 & .196 & .003 \\
\hline $\begin{array}{c}\text { Correlation selling is effective } \\
\text { Sig. (2-tailed) }\end{array}$ & -.151 & 1 & 75 \\
\hline $\begin{array}{l}\text { the current personal Pearson } \\
\text { Pearson Correlation in phy- } \\
\text { sician's chamber? }\end{array}$ & 75 & 75 & $.435^{* *}$ \\
Sig. (2-tailed) &. $.344^{* *}$ & $.435^{* *}$ & 75 \\
$\mathrm{~N}$ & 75 & 75 & 75 \\
\hline
\end{tabular}

**Correlation is significant at the 0.01 level (2-tailed).

Table 10: ANOVA $^{\mathrm{b}}$ (Customer perception and call effectiveness)

\begin{tabular}{|c|c|c|c|c|c|c|}
\hline \multicolumn{2}{|c|}{ Model } & Sum of Squares & $\mathrm{df}$ & Mean Square & $\mathrm{F}$ & Sig. \\
\hline 1 & Regression & 18.863 & 5 & 3.773 & 17.158 & $.000^{\mathrm{a}}$ \\
\hline & Residual & 4.177 & 19 & .220 & & \\
\hline & Total & 23.040 & 24 & & & \\
\hline
\end{tabular}

a. Predictors: (Constant), thier most important benefit to your practice?, management oftenly intrracts with you., how much act as problem solvers/, how do you grade med. reps?, sales representative respond adequately to your quarries.

b. Dependent Variable: med reps contribute towards clinical practice.

The data from physicians (Table 11) also strongly suggest that irrespective of the interactions with the companies' head offices and/or senior management and benefit provided by the sales people, their relationship and evaluation of the medical representatives and the role they play in their interactions with physicians are the significant contributors to their clinical practice. 
Table 11: Coefficients ${ }^{\mathrm{a}}$ (Customer perception and call effectiveness)

\begin{tabular}{|l|c|c|c|c|c|}
\hline \multirow{2}{*}{ Model } & \multicolumn{2}{|c|}{$\begin{array}{c}\text { Unstandardized Co- } \\
\text { efficient }\end{array}$} & $\begin{array}{c}\text { Standardized } \\
\text { Coefficients }\end{array}$ & & Sig. \\
\cline { 2 - 6 } & $\mathrm{B}$ & Std. Error & Beta & $\mathbf{t}$ & .000 \\
\hline 1 (Constant) & 6.540 & .914 & & -.153 & .000 \\
\hline $\begin{array}{l}\text { How do you grade } \\
\text { med. reps? }\end{array}$ & -.499 & .117 & -.519 & -4.271 & .000 \\
\hline $\begin{array}{l}\text { How much act as } \\
\text { problem solvers/ } \\
\text { sales representative }\end{array}$ & -.807 & .188 & .506 & .276 & .785 \\
\hline $\begin{array}{l}\text { Management often- } \\
\text { ly intrracts with you }\end{array}$ & .035 & .127 & .034 & -1.387 & .182 \\
\hline $\begin{array}{l}\text { Their most impor- } \\
\text { tant benefit to your } \\
\text { practice? }\end{array}$ & -.140 & .101 & -.162 & & \\
\hline
\end{tabular}

a. Dependent Variable: med reps contribute towards clinical practice.

Based on these findings alternate hypothesis is accepted that is, long term relationship building and problem solving efforts by the medical representatives (Relationship Marketing) has a significant impact upon the call effectiveness and development of long term mutually beneficent business relationships and maximum return on investments.

The Role of Medical Representative and customers and Supplier's Relationship on call effectiveness:

As discussed in the methodology, the data was analyzed and compared against a standard of 30 for both Medical representatives and physicians (Table $12,13)$. The differences were significant for both medical representatives and

Table 12: One-Sample Test ( Med Reps)

\begin{tabular}{|c|c|c|c|c|c|c|}
\hline & \multicolumn{6}{|c|}{ Test Value $=30$} \\
\hline & \multirow[t]{2}{*}{$\mathrm{t}$} & \multirow[t]{2}{*}{ df } & \multirow[t]{2}{*}{$\begin{array}{l}\text { Sig. (2- } \\
\text { tailed) }\end{array}$} & \multirow[t]{2}{*}{$\begin{array}{l}\text { Mean dif- } \\
\text { ference }\end{array}$} & \multicolumn{2}{|c|}{$\begin{array}{l}95 \% \text { confidence inter- } \\
\text { val of the difference }\end{array}$} \\
\hline & & & & & Lower & Upper \\
\hline $\begin{array}{l}\text { distributor } \\
\text { support } \\
\text { you in RM? }\end{array}$ & -222.540 & 74 & .000 & -27.693 & -27.94 & -27.45 \\
\hline
\end{tabular}


physicians (Table 13), a significant contributor towards the ineffectiveness of the medical representative's sales call and physician's evaluation. Earlier research has clearly established the effect of sale people and supplier's relationship in the marketing strategy and its implementation in both businesses to business and consumer markets (Jones, 2005).

Hence on behalf of findings of the study and the previous researches it is evident that suppliers can play a significant role in relationship building both on medical representatives' and physicians' sides. Strong relationship between medical representatives and suppliers and physicians and suppliers ultimately supports sales people develop strong relationships with the physicians and maximum ROI.

Table 13: One-Sample Test ( Phys)

\begin{tabular}{|l|l|l|l|l|l|l|}
\hline & \multicolumn{3}{|c|}{ Test Value $=30$} \\
\cline { 2 - 7 } & $\mathbf{t}$ & $\mathrm{df}$ & $\begin{array}{l}\text { Sig. (2- } \\
\text { tailed) }\end{array}$ & $\begin{array}{l}\text { Mean dif- } \\
\text { ference }\end{array}$ & \multicolumn{2}{|l|}{$\begin{array}{l}\text { 95\% confidence inter- } \\
\text { val of the difference }\end{array}$} \\
\cline { 5 - 7 } & & & & & Lower & Upper \\
\hline $\begin{array}{l}\text { Rx never } \\
\text { bounce back }\end{array}$ & -193.747 & 24 & .000 & -27.400 & -27.69 & -27.11 \\
\hline
\end{tabular}

The overall findings of this study clearly indicate that very short run and transactional approach of the medical representatives and establish a strong need for the long term relationship focus and customer orientation. Crucial however is, devising a comprehensive system that would ensure an integrative model of Medical representative-physician\&-Suppliers' interaction mainly coordinated and facilitated by the sales people.

\section{Conclusion:}

Spanning the boundary between the firm and the customers, sales people are the only source to develop, maintain and expand long term relationship with the customers. Research shows that technical and complex products that require a service component too, require a greater coordination between the customers and the selling firm (Brown, 2005). Another significant role player would be the digital and social media, that will enable companies to create and manage the maximum of touch points for their customers in view of their academic, personal and professional requirements. In addition companies can also develop their own E-databases in order to make the products' features, benefits and availability related information easy to access. This will also sup- 
port adequate customer relationship and relationship manager's management. This is typically true for pharmaceutical products, as the detail extensiveness and risk usually requires frequent physician and medical representatives' interactions. Dixon and associates recommend the role of a relationship manager to replace the traditional sales people job in this context. Relationship managers are those people who have developed skills and have a command and authority in deploying their skills and companies' resources to develop long lasting mutual interest with the customers. This can be only accomplished when as an effective relationship manager; the sales person is an integral part of the organization, and customer's clinic or hospital and has very close liaisons with the supplier or distributor in order to ensure proper coverage for supply of products. Only then a thorough understanding of the customers' needs, implication of their capabilities, and efficient utilization of resources would be possible. Enabling relationship manager to perform different types of individual roles inside their organization and physician' clinic and develop long term mutually beneficial business relationship with the customers in view of the current highly competitive and dynamic environment.

The findings of this research are quite consistent with the work of Dixon et al (2003) however specific to pharmaceutical industry following aspects are crucial for a successful physician medical representative long term relationship;

The sales person should consider himself as a problem solver or operative to develop long term relationship between the firm and Physician.

> Companies should provide their sales people with sufficient skills command and authority to be an effective Relationship manager.

$>$ There should be an efficient communication system to ensure adequate responses to Physicians' quarries, their academic and professional needs and creating efficient and fluent interactions at different community and individual levels.

$>$ The role of field manager need to be modified as an immediate channel of communication between the management at head office and relationship managers.

$>\quad$ An adequate supplier management system mobilized and managed by the relationship manager would benefit both the firm and physicians. 


\section{Recommendations:}

In their recommendations Dixon et al (2003) recommended a new model for the relationship managers of B2B organizations with the relationship manager playing an embedded role in both the buyer and seller organizations, called as the Embedded Sales Force. Our research however calls for a little modification and some addition of the embedded sales force model based on context and industry while incorporating digital and social media in addition. An integrative model of communication and interaction is developed based on the study outcomes, taking the relationship manager or sales person as the key coordinating factor between the firm physician and the distributor. The basic objective and task is to coordinate marketing, supplier and personal selling in a way that offer synergies in ensuring call effectiveness and ROI. Utilization of social media will enable the medical representative and companies to create new touch points for the physicians in the current personal selling clutter. As evident the model supposes a permanent integration of the relationship manager within the trade of firm, physician and the medicine distributor or supplier to ensure long lasting exchange of value and relationship between the three dimensions of relationship marketing.

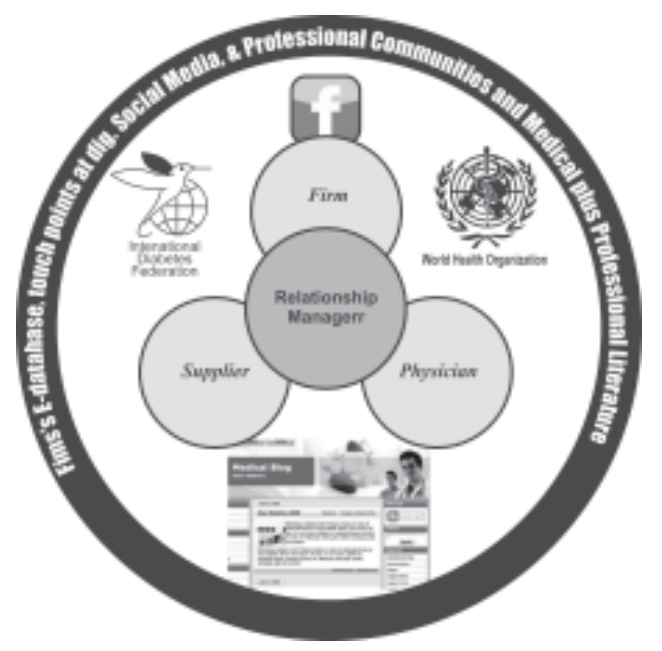

Figure 3

\section{Further Research Implications:}

The theoretical model of relationship manager for pharmaceutical sales people needs further research with special respect to its applicability in the current dynamic environment while adopting the recent digital media. (Internet, social media, medical communities, websites and corporate blogs) 
Further research is needed to develop a comprehensive organizational structure in order to cater the three key dimensions of relationship marketing in an integrated and coordinated manner.

\section{Managerial Implications of the Model: \\ The Relationship Manager-Firm overlap:}

This component of the model emphasizes the extent to which a relationship manager can approach different functional areas inside the organization in order to get support for the day to day interactions with the physicians and also enabling the marketing and other functional areas to effectively communicate with and get insight of the physicians' and market database. Dixon et al. (2003) have put forth two major areas of this interface;

a) How to provide the relationship manager with adequate support \&

b) How to properly manage the activities of a relationship manager.

However, these areas require further research in the pharmaceutical personal selling context based on developing an effective communication and interaction system in view of the latest digital technology.

\section{The Relationship Manager and Customer Overlap:}

Recent practices in pharmaceutical industry involve interacting with physicians in a team oriented way and usually incorporate more than one person to interact with the customer for one product in varied contexts, addressing the same product for different indications and from different perspectives. Called as the co-promotion these practices are now a day very common in the industry, but lack however a long term customer orientation as per the outcomes of the research. Crucial however, is the development of a comprehensive understanding of the interaction for both the sides so as to facilitate an environment of mutual dependency and trust. The greater the extent of relationship manager's customer oriented approach the higher the trust of the customer and stronger the bond between them.

\section{The Relationship Manager and Supplier overlap:}

As discussed earlier the outcomes of the study showed a significant gap on the part of distributor or firm's management to better incorporate the supplier's role in long term relationship building. Neither the sales people nor 
the physicians were satisfied with the role of distributor in developing relations or facilitating the sales cycle. Improving supplier's efficiency and its incorporation in the relationship building have its implications in the following three areas;

a) Increasing relationship manager's efficiency in responding to physicians' professional and academic needs and prescriptions.

b) Preventing prescriptions bounce back thus improving sales and reducing customers defections \&

c) Finally the resources \& coverage of distributor can be effectively used by both the relationship manager and firm to get market and physician responses and utilize their database to interpret and forecast market trends and performances.

\section{References:}

Biong, H., \& Selnes, F. (1995). Relational selling behavior and skills in long-term industrial buyer-seller Relationships. International Business Review, Volume 4, Issue 4, Pages 483-498.

Blackett, T. Robins, R. (2001). The role of branding in pharmaceutical industry, Edited by PALGRAVE Hound mills, Basingstoke, Hampshire RG21 6XS.

Boles et al; (1997). Doney and Cannon et al; (1997). Ramsey and Sohi (1997). Journal of management, 57.

Bradford, K. Liu, Y. Xu, J. \& Weitz, B. (2008a). Relationship orientation and sales person effectiveness. In Presentation at Erin Anderson Research Conference, Philadelphia: The Wharton School, October 17-19.

Butler, G. (2004). Strategic trends facing the pharmaceutical industry and their implications for marketing skills development. International Journal of Medical Marketing, Vol. 3, 1 65-68.

Chartered Institute of Marketing, (1994). Marketing - the challenge of change: A major study into the future of marketing in key British enterprises. CIM, London.

Christopher, M. (1995). Networks and logistics: Managing supply chain relationships, paper presented to the third international colloquium in Relationship Marketing. Monash University, Melbourne.

Christopher, M.G. Payne, A.F. \& Ballantyne, D. (1991). Relationship Marketing: Bringing quality, customer service and marketing together. Butterworth-Heinemann, Oxford). 
Craven, D., \& Piercy, N. (1994). Journal of Marketing, Vol. 70 (3). 8.

David C. Edelman. (2010) Harvard Business Revie. Spotlight on Social Media and the new rules of Branding, December. p, 63.

Delmirio. (2003).Relationships Marketing. International Business Review Volume 4, Issue 4, Pages 483-498.

Dixon, A. L. Gassenheimer, J. \& Barr T. F. (2003). Identifying the lone-wolf: a team perspective. Journal of Personal Selling and Sales Management, 23, 205-219.

Doyle, P. (1995). Marketing in the new Millennium. European Journal of Marketing, 29, 13, $23-41$.

Fornell and Wernerfelt. (1995). Customer Satisfaction, Productivity, and Profitability: Differences between Goods and Services. Marketing Science, 16(2): 129-45.

Foster, B. \& Cadogan, J. (2000). Marketing Intelligence and Planning, 18/4. 185-199.

Gronroos, C. (1990). Marketing redefined. Management Decision, 28, No. 8, 5-9.

Gronroos, C. (1990). Relationship approach to marketing in services contexts: The marketing and organizational behavior interface. Journal of Business Research.

Hunt S.D. \& Morgan, R.M. (1994). Relationship marketing in the era of network competition. Marketing Management, 3, No. 1, 18-28.

Hunter, G. K. \& Perreault, W. D. (2007). Making sales technology effective. Journal of Marketing, 71, 16-34.

IMS health $3^{\text {rd }}$ Qtr. (2010). Drugs Control Organization, Ministry of Health, Pakistan.

Jackson, B. (1985). Build customer relationships that last. HBR, November/December, $120-128$.

Jones, E. Brown, S. Zoltners, A. \& Weitz, B. (2005a). Changing environment of selling and sales management. Journal of Personal Selling and Sales Management, 25, 104-113.

Kevin Lane Keller. The Strategic brand management. $3^{\text {rd }}$ edition, p. 163.

Kottler, P. (1992). Total marketing. Business Week Advance, executive brief-2.

Masood I. Ibrahim M. Hassali MA. \& Ahmaed M. (2009). Evolution of Marketing Techniques, Adoption in Pharmaceutical Industry And Related Issues: A Review. Journal of Clinical and diagnostic Research. December, Vol.6, Issue 3, 1942-1952. 
Meyer R. (2010). Where do we go from here? Pharma marketing; (www.worldofdtcmarketing.com).

Mishra, A. (2006). Problems and Prospects of Sales Promotion in Pharmaceutical Marketing Communication. Department of Business Communication Aryan Institute of Engineering and Technology. Bhubaneswar.

Morgan, R.M. \& Hunt, S.D. (1994). The commitment trust theory of Relationship marketing, Journal of Marketing, 58, 20-38.

OSEC (2008).Pakistan Pharmaceutical sector OSEC, 17th October, Karachi. Pages 483-498.

Palmer, A.J. (1995). Relationship marketing, "local implementation of a universal concept". Business Review, Volume 4, Issue 4.Pages; 471-481.

Prosser, H. \& Walley, T. (2003). Understanding why GPs see pharmaceutical representatives: a qualitative interview study. British Journal of General Practice, April. Pages 305-311.

Reichheld, F.F. \& Sasser, W.E. (1990). Zero defections: Quality comes to services. Harvard Business Review, September/October. 105-111.

Reichheld, F.F. (1993). Loyalty-based management, Harvard Business Review, March/April. 64-73.

Relationship Marketing Strategy and implementation. $3^{\text {rd }}$ edition. Pages 270-271.

Robeerto, C. (2004).Findings from an Empirical Study. 20th Annual IMP Conference, Copenhagen.

Robert D. The Economist (April 1994), death of Brand Manager, 79-80.

Schlesinger, L.A. \& Heskett, J.L. (1991). Breaking the cycle of failure in services. Sloan Management Review, spring, 17-28.

Steven B. Peterson. \& Robert, A. (1994). The effect of effort on sales performance and job satisfaction. Journal of Marketing, April 58, 2; ABI/INFORM Global pg. 70.

Too Many Reps Minimizing Impact of Personal Selling. G \& S Research Study on Pharmaceutical Sales. (2007). Business Wire.

Tuli, K. R., Kohli, A. \& Bharadwaj, S. (2007). Rethinking customer solutions: from product bundles to relational processes. Journal of Marketing, 71, 1-17.

Webster Jr. (1976). The role of the industrial distributor in marketing strategy. The Journal of Marketing, The Journal of Marketing, Vol. 40, No. 3, pp. 10-16. 